\title{
Kodifikasi dan Efektivitas Kebijakan Fiskal untuk Menurunkan Emisi Gas Rumah Kaca pada Industri Semen, Baja dan Pulp
}

\author{
Joko Tri Haryanto ${ }^{1}$ \\ Berly Martawardaya ${ }^{2}$
}

\begin{abstract}
Industrial activity is known as one of the major contributors of greenhouse gas emissions (GHG). Sources of GHG emissions from the industrial sector include energy inputinput, the inputinput of non-energy, industrial processes and industrial waste. Thus, the industrial sector, listed as one of the important sectors in the National Action Plan (NAP) Reduction of GHG emissions. Implementation of mitigation actions in the industrial sector clearly requires appropriate regulatory framework. The right combination of policy and fiscal instruments needed to encourage industry players become actively involved in the national effort to reduce GHG emissions in Indonesia. The problem, the need for coordination regulations related efforts to reduce GHG emissions in the industrial sector of each Ministry / Institutions ( $K$ / L) are associated in particular Ministry of Finance Regulation (PMK and the Regulation of the Minister of Industry (Permenindustri). For that study was conducted using the framework regulatory analysis for the creation of regulatory coordination between the PMK and Permenindustri. Through the codification mechanism, expectedd to increase the effectiveness of fiscal policy to reduce GHG emissions in the industrial sector.
\end{abstract}

\section{Keywords:}

GHG emission; mitigation; fiscal incentive.

\begin{abstract}
Abstrak
Kegiatan industri dikenal sebagai salah satu kontributor utama emisi gas rumah kaca (GRK). Sumber emisi GRK dari sektor industri meliputi input energi, masukan non-energi, proses industri dan limbah industri. Dengan demikian, sektor industri, tercatat sebagai salah satu sektor penting dalam Rencana Aksi Nasional (RAN) Penurunan Emisi GRK. Pelaksanaan aksi mitigasi di sektor industri jelas memerlukan kerangka peraturan yang tepat. Kombinasi yang tepat dari kebijakan dan instrumen fiskal yang diperlukan untuk mendorong pelaku industri menjadi aktif terlibat dalam upaya nasional untuk mengurangi emisi GRK di Indonesia. Permasalahannya, perlu adanya koordinasi peraturan yang terkait upaya penurunan emisi GRK sektor industri di masingmasing Kementerian/Lembaga (K/L) yang terkait khususnya Peraturan Menteri keuangan (PMK dan Peraturan Menteri Perindustrian (Permenindustri). Untuk itulah penelitian ini dilakukan dengan menggunakan kerangka analisis regulasi demi terciptanya koordinasi regulasi antara PMK dan Permenindustri. Melalui mekanisme kodifikasi tersebut, diharapkan terjadi peningkatan efektivitas kebijakan fiskal untuk mengurangi emisi GRK di sektor industri.
\end{abstract}

\footnotetext{
${ }^{1}$ Peneliti Pusat Kebijakan Pembiayaan Perubahan Iklim dan Multilateral, Badan Kebijakan Fiskal, Kementerian Keuangan

Email: djohar78@gmail.com

2 Mahasiswa Fakultas Ekonomi, Universitas Indonesia.

Email: bmartawardaya@gmail.com.
} 


\section{Kata Kunci:}

Emisi GRK; mitigasi; insentif fiskal.

\section{Pendahuluan}

Pemerintah Indonesia telah berkomitmen untuk menurunkan emisi gas rumah kaca (GRK) pada tahun 2020 sebesar 26 persen dengan pendanaan APBN/APBD serta sampai 41 persen dengan dukungan internasional. Untuk mencapainya, telah disusun Rencana Aksi Nasional Penurunan Emisi Gas Rumah Kaca (RAN-GRK) yang akan ditindak lanjuti dengan "Nationally Appropriate Mitigation Actions" (NAMAs) berdasarkan United Nations Framework Convention on Climate Change (UNFCCC). NAMAs adalah kumpulan kebijakan dan kegiatan yang dilaksanakan untuk mencapai komitmen penurunan emisi rumah kaca.

Kegiatan industri adalah salah satu kontributor utama emisi gas rumah kaca yang meliputi input energi dan non-energi, proses industri dan limbah/sisa hasil industri. Sektor industri, sebagaimana tercantum dalam RAN-GRK memiliki peranan penting dalam pencapaian target penurunan emisi GRK atau mitigasi perubahan iklim. Berdasarkan studi Bank Dunia (2009), empat sektor yang merupakan emitter terbesar adalah semen, besi dan baja, tekstil serta pulp dan kertas.

Walaupun tekstil juga merupakan salah satu emitor terbesar, tapi karakteristiknya yang tersebar dan terdiri dari banyak pemilik merupakan hambatan tersendiri dalam melakukan aksi-aksi penurunan emisi gas rumah kaca. Industri semen, baja serta pulp dan kertas yang lebih terkonsentrasi menjadi fokus dalam studi ini. Tiga sumber utama emisi gas adalah input energi, input non-energi, dan sisa hasil produksi. Pemahaman yang lebih dalam mengenai produksi manufaktur di ketiga sektor tersebut akan memberikan dasar yang lebih kuat dalam revisi regulasi dan struktur insentif.
Implementasi kegiatan mitigasi dalam sektor industri memerlukan kerangka kebijakan. Kombinasi kebijakan, program dan instrumen dibutuhkan untuk mendorong pelaku industri untuk terlibat aktif dalam usaha nasional dalam menurunkanemisi GRK. Instrumen ekonomi khususnya dapat menjadi insentif dalam implementasi tersebut. PAKLIM, GIZ pada tahun 2011 telah melakukan studi untuk kompilasi instrumen ekonomi dan mitigasi untuk industri. Studi tersebut telah menjabarkan contoh implementasi dan best practice dari negara lain serta menganalisis kondisi dan kebutuhan akan instrumen ekonomi di Indonesia.

Mengingat pentingnya persoalan tersebut, studi ini bertujuan untuk melakukan kodifikasi: a) berbagai instrumen fiskal yang berlaku dan ditujukan pada sektor industri; b) penggunaan instrumen fiskal oleh industri; c) mekanisme sosialisasi yang umum digunakan; d) efektivitas instrumen dalam mencapai dampak yang diinginkan dan dalam mengurangi emisi GRK. Studi ini diharapkan menjadi basis untuk studi selanjutnya tentang penurunan emisi gas rumah kaca pada sektor industri di Indonesia secara lebih mendalam.

\section{Metodologi}

Metode penelitian pada dasarnya merupakan cara ilmiah untuk mendapatkan informasi dengan tujuan dan kegunaan tertentu . Metode penelitian yang digunakan dalam kajian ini lebih bersifat deskriptif kuantitatif dengan menggunakan analisis kodifikasi regulasi untuk mendapatkan persepsi atas regulasi yang diatur. Hal ini akan dijadikan dasar di dalam melakukan rekomendasi ke depannya demi menghindari terjadinya overlapping regulasi.

Adapun jenis data yang digunakan dalam studi ini sebagian besar merupakan 
jenis data sekunder yang didapatkan dari beberapa instansi yang berwenang terhadap data-data tersebut. Data sekunder yang utama adalah data terkait Peraturan Pemerintah (PP), Peraturan Menteri Keuangan (PMK), Peraturan Menteri Perindustrian (Permenindustri) serta beberapa pendukung yang didapatkan dari Kamar Dagang dan Industri Nasional (KADIN) serta Badan Pusat Statistik (BPS). Untuk mendapatkan stakeholder's sperception, di dalam studi ini juga dilakukan wawancara dan diskusi dengan pemangku kepentingan terkait dengan efektivitas serta kemudahan birokrasi dari masing-masing regulasi yang mengatur terkait sektor industri khususnya yang bersifat lintas K/L.

Sedangkan metode analisis yang digunakan digunakan dalam studi ini adalah metode statistik deskriptif dengan menggunakan berbagai alat analisis berupa tabel, gambar dan diagram untuk mendapatkan kesimpulan terkait dengan kodifikasi yang dimaksudkan. Analisis tabel ditujukan sebagai tool di dalam melakukan sintesis regulasi, sementara analisis gambar dan diagram lebih ditujukan bagi penjelasan uraian terkait kondisi masing-masing industri. Hasil dari kodifikasi inilah nantinya yang akan menjadi dasar bagi penulis untuk memberikan kesimpulan serta rekomendasi kebijakan kepada seluruh stakeholders yang terkait.

\section{Peraturan dan Instrumen Fiskal bagi Mitigasi Perubahan Iklim dan Perlindungan Lingkungan}

Pemerintah Indonesia telah menyadari pentingnya menyelenggarakan suatu proses pembangunan yang berperan bagi peningkatan pendapatan dan kesejahteraan masyarakat dengan didasari oleh prinsip pembangunan berkelanjutan dan berwawasan lingkungan sesuai dengan amanah Pasal 33 ayat 4 Undang Undang Dasar Negara Republik Indonesia Tahun 1945, termasuk pada tiga industri penghasil emisi terbesar yang telah dijelaskan pada bagian sebelumnya, yaitu baja, semen, serta pulp dan kertas. Komitmen pemerintah tersebut ditunjukkan melalui penyusunan undang-undang dan peraturan yang mengatur penyelenggaraan usaha di sektor-sektor tersebut, khususnya dalam bentuk penyusunan instrumen-instrumen fiskal untuk mendukung pembangunan berwawasan lingkungan di sektor tersebut terutama dalam upaya mitigasi perubahan iklim.

Berdasarkan telaah peneliti, berbagai peraturan dan instrumen fiskal bagi mitigasi perubahan iklim dan perlindungan lingkungan pada sektor baja, semen, serta pulp dan kertas tersebut dapat dikategorisasi sesuai dengan tahapan usaha pada setiap industri, yaitu sebagai berikut :

a. Memulai usaha (starting business)

b. Input energi

c. Input non-energi

d. Operasi usaha

e. Manajemen gas/zat buang (waste management)

\section{Memulai usaha (starting business)}

Berdasarkan identifikasi yang dilakukan terhadap undang-undang dan peraturan yang ada, saat ini tidak ada peraturan/instrumen yang spesifik yang mengatur secara khusus suatu insentif/disinsentif bagi industri baja, semen serta pulp dan kertas pada tahapan memulai usaha khususnya dalam upaya mitigasi perubahan lingkungan. Peraturan terkait yang ada hanyalah untuk industri pionir yang memungkinkan industri baja untuk turut dapat memanfaatkannya. Deskripsi atas kedua peraturan tersebut disajikan pada Tabel 1.

Kedua peraturan, yaitu PMK130/2011 dan PM Perindustrian 93/2011 yang saling berkaitan tersebut, memberikan insentif instrumen pembebasan PPh Badan 5-10 tahun, di mana setelah masa tersebut dapat diperoleh pengurangan $\mathrm{PPh}$ Badan 50 persen selama dua tahun. Bagi industri baja, walau tidak disebutkan spesifik bertujuan untuk 
Tabel 1.

Instrumen Fiskal Mitigasi Perubahan Iklim dan Perlindungan Lingkungan-Tahap Memulai Usaha

\begin{tabular}{|c|c|c|c|c|c|}
\hline Sektor & Peraturan & Tentang & Insentif Fiskal & Syarat & Analisis Kesesuaian \\
\hline \multirow[t]{2}{*}{ Baja } & $\begin{array}{l}\text { PMK } \\
130 / 2011\end{array}$ & $\begin{array}{l}\text { Fasilitas Pembebasan/ } \\
\text { Pengurangan PPh } \\
\text { Badan }\end{array}$ & $\begin{array}{l}\text { Pembebasan } \\
\text { PPh Badan 5-10 } \\
\text { tahun (setelahnya } \\
\text { pengurangan PPh } \\
\text { Badan } 50 \text { persen } \\
\text { selama } 2 \text { tahun) } \\
\end{array}$ & $\begin{array}{l}\text { Industri } \\
\text { Pionir }\end{array}$ & \multirow{2}{*}{$\begin{array}{l}\text { - (berpotensi) efektif } \\
\text { - Teknologi baru } \\
\text { mendukung industri } \\
\text { baja beroperasi } \\
\text { dengan lebih efisien, } \\
\text { hemat energi dan } \\
\text { ramah lingkungan, } \\
\text { dan mendukung } \\
\text { upaya mitigasi } \\
\text { perubahan iklim. }\end{array}$} \\
\hline & $\begin{array}{l}\text { PMPerindus- } \\
\text { trian } \\
\text { No.93/2011 } \\
\text { (Pelaksanaan } \\
\text { PMK } \\
\text { 130/2011) } \\
\end{array}$ & $\begin{array}{l}\text { Fasilitas Pembebasan/ } \\
\text { Pengurangan PPh } \\
\text { Badan }\end{array}$ & $\begin{array}{l}\text { Pembebasan } \\
\text { PPh Badan 5-10 } \\
\text { tahun, setelahnya, } \\
\text { pengurangan PPh } \\
\text { Badan } 50 \text { persen } \\
\text { selama } 2 \text { tahun } \\
\end{array}$ & $\begin{array}{l}\text { Industri } \\
\text { Pionir }\end{array}$ & \\
\hline Semen & & & Tidak tersedia & & \\
\hline Pulp & & & Tidak tersedia & & \\
\hline
\end{tabular}

Sumber: Data diolah

mengurangiemisi karbon, pemberian instrumen fasilitas pembebasan/pengurangan PPh Badan yang berlaku bagi pendirian perusahaan baru yang memenuhi kriteria industri pionir, yaitu dengan adanya persyaratan penggunaan teknologi baru, dinilai tepat dan dapat berpotensi menjadi insentif yang efektif.

Hal ini akan memberikan insentif munculnya perusahaan baru yang telah mengaplikasikan teknologi terkini, yang diharapkan juga menghasilkan emisi lebih rendah, yang memang telah tersedia dapat mendukung ketersediaan produk baja yang dibutuhkan oleh berbagai industri hilir di dalam negeri namun berproduksi pada tingkat penggunaan energi/bahan material yang efisien sehingga tetap mendukung upaya mitigasi terhadap perubahan iklim.

Insentif fiskal yang diatur dalam PMK 130/2011 dan PM Perindustrian 93/2011 tersebut belum dapat dinilai dampak penerapannya. Hal ini dikarenakan sejak dikeluarkannya peraturan tersebut hingga saat ini, belum ada perusahaan yang disetujui untuk menerima insentif tersebut. Berdasarkan hasil diskusi dengan Kementerian Keuangan dan KADIN, sejauh ini baru terdapat beberapa perusahaan yang mengajukan untuk memperoleh Tax Holiday.
Kedua perusahaan tersebut dinilai layak oleh Tim Verifikasi Kementerian Perindustrian dan Kementerian Keuangan untuk mendapat insentif Tax Holiday. Namun, karena proses pengambilan keputusan juga melibatkan Kementerian Koordiantor Bidang Ekonomi dan Presiden, menyebabkan keputusan akhir yang diajukan pada bulan Maret 2012 masih belum diputuskan sampai sekarang (Desember 2012).

Periode pemberian insentif Tax Holiday, yang berkisar dari lima sampai sepuluh tahun dengan terbuka perpanjangan 50 persen pembebasan pajak untuk dua tahun, belum berdasarkan kepada kriteria tertentu yang jelas dan tercantum dalam regulasi tapi diserahkan ke diskresi Menteri Keuangan (Martawardaya dan Agriva, 2012). Mengingat manfaat pajak yang sangat tinggi, banyak perusahaan yang tertarik pada insentif ini. Insentif Tax Holiday, yang sedang pada tahap review dan revisi, memerlukan kriteria periode yang lebih tegas, waktu pengurusan yang pendek dan pencantuman kriteria lingkungan serta pengurangan emisi secara eksplisit. Perlu dicatat bahwa kebijakan Tax Holiday di Thailand pada tahun 2010 hanya diberikan pada usaha terkait konservasi/alternatif energi, material 
eco-friendly dan teknologi tinggi untuk periode delapan tahun.

\section{Input energi}

Berdasarkan identifikasi yang dilakukan terhadap undang-undang dan peraturan yang ada, saat ini hanya terdapat satu peraturan yang secara spesifik mengatur pemberian insentif bagi industri tertentu, yaitu industri semen, di mana secara eksplisit telah mengatur insentif fiskal sebagai upaya mitigasi perubahan iklim. Namun bagi industri baja serta pulp dan kertas, hingga saat ini belum ada peraturan spesifik yang mengatur tentang pemberian insentif terkait input energi. Tetapi secara umum terdapat lima peraturan terkait perlindungan lingkungan yang berlaku bagi seluruh industri perihal input energi, yaitu UU/ peraturan yang mengatur tentang penanaman modal, konservasi energi, dan penggunaan bahan bakar nabati. Deskripsi atas peraturanperaturan tersebut disajikan pada Tabel 2.

Peraturan yang mengatur tentang road map Pengurangan Emisi $\mathrm{CO}_{2}$ Industri Semen adalah peraturan yang pertama dikeluarkan terkait pengurangan emisi $\mathrm{CO}_{2}$, di antara industriindustri lainnya. Pada industri semen, diketahui pembakaran energi yang mengandung karbon

Tabel 2.

Instrumen Fiskal Mitigasi Perubahan Iklim dan Perlindungan Lingkungan-Tahap Input Energi

\begin{tabular}{|c|c|c|c|c|c|}
\hline Sektor & Peraturan & Tentang & Insentif Fiskal & Syarat & Analisis Efektivitas \\
\hline Semen & $\begin{array}{l}\text { PM } \\
\text { Perindus- } \\
\text { trian } \\
12 / 2012\end{array}$ & $\begin{array}{l}\text { Peta } \\
\text { Panduan } \\
\text { (road map) } \\
\text { Pengu- } \\
\text { rangan } \\
\text { Emisi } \mathrm{CO}_{2} \\
\text { Industri } \\
\text { Semen }\end{array}$ & insentif fiskal & $\begin{array}{l}\text { Industri yang } \\
\text { menerapkan } \\
\text { pemanfaatan gas } \\
\text { buang sebagai } \\
\text { sumber energi } \\
\text { (heat recovery) }\end{array}$ & $\begin{array}{l}\text { - (berpotensi) efektif } \\
\text { - Adanya insentif fiskal akan } \\
\text { mendorong industri untuk } \\
\text { menurunkan emisi } \mathrm{CO}_{2^{\prime}} \text { antara } \\
\text { lain melalui penggunaan gas } \\
\text { buang/biofuel, melakukan } \\
\text { kegiatan/proses produksi } \\
\text { yang hemat energi, dan } \\
\text { menyediakan alat yang hemat } \\
\text { energi. } \\
\text { - membutuhkan peraturan } \\
\text { pelaksana tambahan untuk } \\
\text { merinci jenis dan prosedur } \\
\text { memperoleh insentif fiskal } \\
\text { yang ditawarkan }\end{array}$ \\
\hline \multirow[t]{3}{*}{ Semua } & \multirow[t]{3}{*}{ UU 25/2007 } & \multirow[t]{3}{*}{$\begin{array}{l}\text { Penanam- } \\
\text { an Modal }\end{array}$} & $\begin{array}{l}\text { Pembebasan/ } \\
\text { keringanan bea } \\
\text { masuk impor barang } \\
\text { modal/mesin/per- } \\
\text { alatan (belum di } \\
\text { produksi di DN) } \\
\text { dan bahan baku/ } \\
\text { bahan penolong }\end{array}$ & \multirow[t]{3}{*}{$\begin{array}{l}\text { - Pionir } \\
\text { - menjaga } \\
\text { kelestarian } \\
\text { lingkungan } \\
\text { hidup }\end{array}$} & \multirow{3}{*}{$\begin{array}{l}\text { - (berpotensi) efektif } \\
\text { - terkait input energi, industri } \\
\text { baja, semen serta pulp dan } \\
\text { kertas dapat memanfaatkan } \\
\text { insentif fiskal berupa } \\
\text { pembebasan/keringanan bea } \\
\text { masuk impor khususnya } \\
\text { untuk penggunaan bahan } \\
\text { baku/bahan penolong yang } \\
\text { terkait dengan upaya menjaga } \\
\text { kelestarian lingkungan hidup, } \\
\text { termasuk dalam upaya mitigas } \\
\text { perubahan iklim. } \\
\text { - membutuhkan peraturan } \\
\text { pelaksana tambahan untuk } \\
\text { merinci prosedur memperoleh } \\
\text { insentif fiskal yang ditawarkan } \\
\text { dan konsistensi peraturan yang } \\
\text { telah ada }\end{array}$} \\
\hline & & & $\begin{array}{l}\text { Pembebasan/ } \\
\text { penangguhan } \\
\text { PPN impor barang } \\
\text { modal/mesin/ } \\
\text { peralatan (belum } \\
\text { diproduksi di DN) }\end{array}$ & & \\
\hline & & & $\begin{array}{l}\text { Penyusutan/ } \\
\text { amortisasi yang } \\
\text { dipercepat } \\
\text { Keringanan PBB }\end{array}$ & & \\
\hline
\end{tabular}

Bersambung ke halaman 83 
Sambungan dari halaman 82

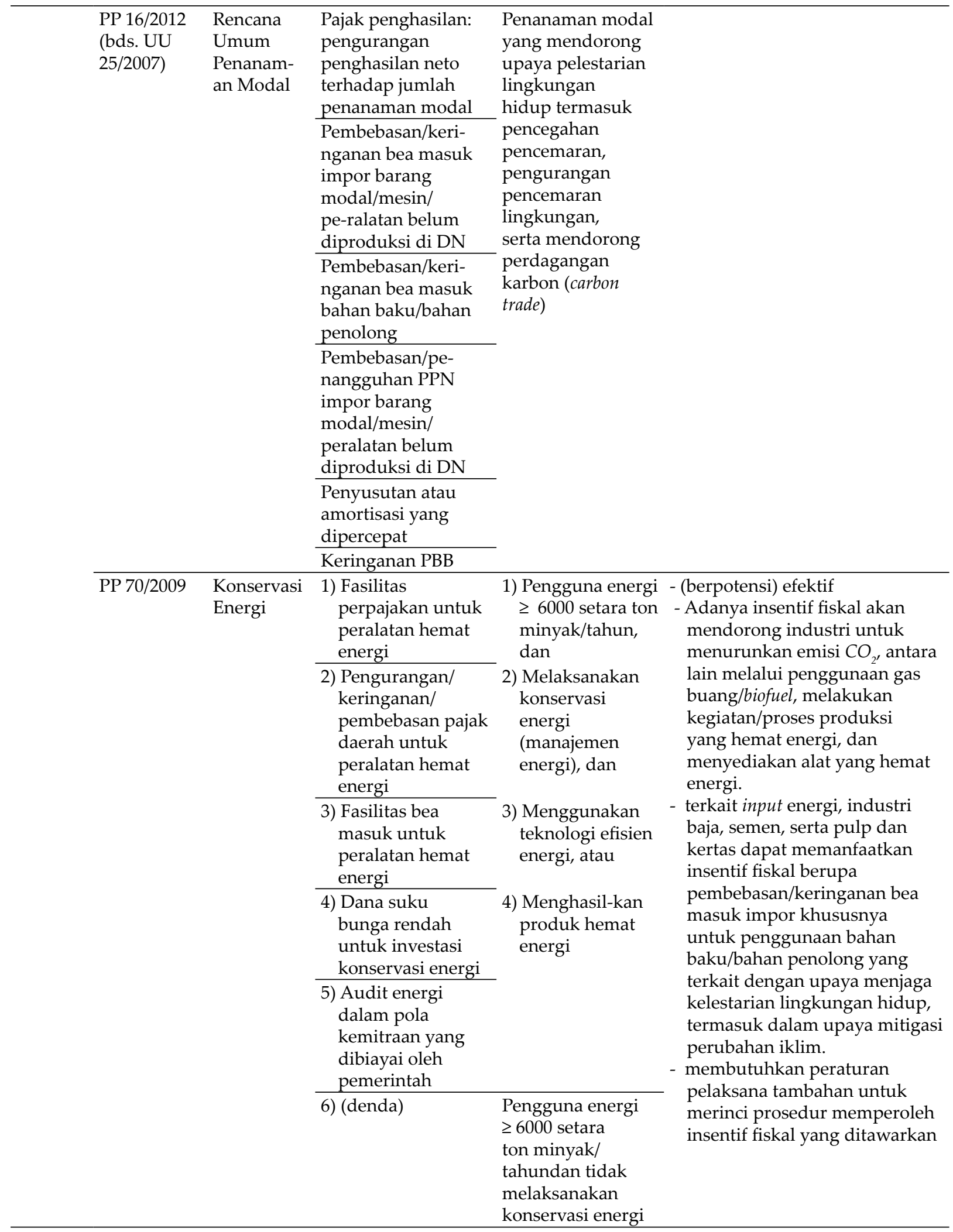


Sambungan dari halaman 83

\begin{tabular}{|c|c|c|c|c|}
\hline UU 47/2009 & $\begin{array}{l}\text { APBN } \\
\text { Tahun } 2010\end{array}$ & $\begin{array}{l}\text { pajak ditanggung } \\
\text { pemerintah (DTP) } \\
\text { atas: PPN Bahan } \\
\text { Bakar Nabati (BBN) } \\
\text { Rp 1.000.000.000.000 }\end{array}$ & & \multirow{2}{*}{$\begin{array}{l}\text { - (berpotensi) efektif } \\
\text { - Adanya insentif fiskal akan } \\
\text { mendorong industri untuk } \\
\text { menurunkan emisi } C \mathrm{C}_{2^{\prime}} \text { antara } \\
\text { lain melalui penggun gas } \\
\text { buang/biofuel/bahan bakar } \\
\text { nabati } \\
\text { - membutuhkan peraturan } \\
\text { pelaksana tambahan untuk } \\
\text { merinci jenis dan prosedur } \\
\text { memperoleh insentif fiskal } \\
\text { yang ditawarkan }\end{array}$} \\
\hline $\begin{array}{l}\text { PMK } \\
156 / 2009\end{array}$ & $\begin{array}{l}\text { PPN } \\
\text { Ditang- } \\
\text { gung } \\
\text { Pemerintah } \\
\text { Atas } \\
\text { Penyerahan } \\
\text { Bahan } \\
\text { Bakar } \\
\text { Nabati Di } \\
\text { DN }\end{array}$ & $\begin{array}{l}\text { PPN Ditanggung } \\
\text { Pemerintah, pagu: } \\
\text { Rp } 180 \mathrm{M}\end{array}$ & $\begin{array}{l}\text { Penyerahan Bahan } \\
\text { Bakar Nabati }\end{array}$ & \\
\hline \multirow[t]{2}{*}{$\begin{array}{l}\text { PMESDM } \\
14 / 2012\end{array}$} & $\begin{array}{l}\text { Manajemen } \\
\text { Energi }\end{array}$ & $\begin{array}{l}\text { audit energi dalam } \\
\text { pola kemitraan } \\
\text { yang dibiayai oleh } \\
\text { pemerintah }\end{array}$ & $\begin{array}{l}\text { Pengguna Sumber } \\
\text { Energi/Energi } \geq \\
6.000 \text { setara ton } \\
\text { minyak/tahun, } \\
\text { melakukan } \\
\text { manajemen } \\
\text { energi selama } \\
\text { periode tiga tahun } \\
\text { berturut-turut, } \\
\text { menurunkan } \\
\text { konsumsi energi } \\
\text { spesifik } \geq 2 \text { persen/ } \\
\text { tahun }\end{array}$ & \multirow[t]{2}{*}{$\begin{array}{l}\text { - (berpotensi efektif) } \\
\text { agar seluruh industri } \\
\text { melaksanakan manajemen } \\
\text { energi mendukung mitigasi } \\
\text { perubahan iklim }\end{array}$} \\
\hline & & denda & $\begin{array}{l}\text { Pengguna } \\
\text { sumber energi } \\
\text { dan pengguna } \\
\text { energi tidak } \\
\text { melaksanakan } \\
\text { manajemen energi }\end{array}$ & \\
\hline
\end{tabular}

Sumber: Data diolah

menghasilkan $\mathrm{CO}_{2}$, sekitar 0,869 tons $\mathrm{CO}_{2}$ per ton clinker, yang dihasilkan dalam proses calcination $(0,525$ tons), proses pembakaran energi khususnya batubara (0.298 tons), dan pembakaran energi pada pembangkit (power plant) Produksi cement clinker dari batu gamping (limestone) dan batu kapur (chalk) digunakan dengan cara memanaskan limestone hingga suhu di atas $950^{\circ} \mathrm{C}$ menjadi proses utama yang membutuhkan energi.

Cara yang potensial untuk mengurangi konsumsi energi dan emisi $\mathrm{CO}_{2}$ dalam produksi semen ialah melalui perbaikan kegiatan/proses industri semen (pyroprocessing). Perbaikan proses akan menghasilkan manajemen energi yang lebih baik, meningkatkan kualitas peralatan yang diperlukan (contohnya wet kilns, preheater dan precalciners), mengadopsi teknologi baru dalam proses produksi (pyroprocessing, contohnya fluidised bed systems), dan pada jangka panjang menciptakan proses penelitian dan pengembangan (research and development) untuk membangun konsep baru dalam proses produksi semen. Dampak positif cara-cara yang diusulkan ini, industri semen dapat mengurangi konsumsi energi sebesar 30 persen atau sekitar 3.407.650 Jouls/tonne dan mengurangi emisi $\mathrm{CO}_{2}$ sebesar 13 persen atau hingga 75.3 Mt/year (ClimateTechWiki, 2012).

Namun diketahui bahwa 20-40 persen dari total biaya produksi industri semen digunakan untuk pembiayaan penggunaan energi, sementara perusahaan pada industri semen memiliki keterbatasandana untuk 
melakukan perbaikan tersebut, sehingga insentif fiskal dari pemerintah dapat meningkatkan kemampuan perusahaan guna melakukan perbaikan. Dengan demikian pemberian insentif fiskal sebagaimana yang diatur dalam PM Perdagangan 12/2012 dinilai berpotensi efektif dapat membantu perusahaan pada industri semen dalam menggunakan input energi dan mendukung upaya mitigasi perubahan iklim.

Baik UU 25/2007 maupun PP 16/2012 -yang didasari oleh UU 25/2007, yang mengatur tentang penanaman modal, serta PP 70/2009 yang mengatur tentang konservasi energi, maupun UU 47/2009 dan PMK 156/2009 yang mengatur tentang penggunaan bahan bakar nabati, kesemuanya dapat dimanfaatkan oleh seluruh industri. Insentif fiskal yang ditawarkan oleh masing-masing peraturan sebagaimana yang disajikan dalam Tabel 2 tersebut dinilai berpotensi efektif, karena pada dasarnya untuk melakukan efisiensi energi sekaligus pengurangan emisi $\mathrm{CO}_{2}$ dapat dilakukan melalui prosedur:

a. Perubahan proses manufaktur dan produksi (termasuk pergantian alat produksi agar dapat menggunakan energi secara lebih efisien).

b. Menyesuaikan komposisi kimia dari semen

c. Mengganti bahan bakar fosil dengan biomass atau gas buang

Namun efektifitas kebijakan-kebijakan tersebut belum dapat dievaluasi secara karena aturan yang ada masih belum didukung oleh peraturan pelaksana untuk memperoleh insentif fiskal yang ditawarkan. PP 70/2009 menawarkan berbagai insentif fiskal, namun baru terdapat aturan pelaksana mengenai insentif audit energi dalam pola kemitraan yang dibiayai oleh pemerintah dan disinsentif denda, yaitu pada PMESDM 14/2012 tentang Manajemen Energi. Insentif pola kemitraan ini terhitung sebagai bagian insentif fiskal karena pemerintah mengeluarkan sejumlah dana untuk pembiayaan kemitraan tersebut.

PM ESDM 14/2012 mengatur tentang Manajemen Energi menawarkan insentif audit energi dalam pola kemitraan yang dibiayai oleh pemerintah bagi pengguna sumber energi/energi $\geq 6000$ setara ton minyak/ tahun dan melakukan manajemen energi selama periode tiga tahun berturut-turut serta menurunkan konsumsi energi spesifik $\geq 2$ persen/tahun dan denda bagi pengguna sumber energi dan pengguna energi yang tidak melaksanakan manajemen energi. Peraturan tersebut berpotensi mendukung upaya mitigasi perubahan iklim. Sebagaimana telah disebutkan sebelumnya, efisiensi energi sekaligus pengurangan emisi $\mathrm{CO}_{2}$ dapat dilakukan melalui prosedur:

a. Perubahan proses manufaktur dan produksi (termasuk pergantian alat produksi agar dapat menggunakan energi secara lebih efisien).

b. Menyesuaikan komposisi kimia dari semen

c. Mengganti bahan bakar fosil dengan biomass atau gas buang

Sebagai gambaran terhadap diperlukannya insentif bagi input energi antara lain dapat dipaparkan sebagai berikut. Bagi industri baja, sumber emisi utama berasal dari konsumsi energi seperti penggunaan seperti bahan bakar diesel di penambangan dalam, penggunaan gas alam untuk memanaskan taconite, dan listrik untuk proses reduction iron plant (DRI), pelletizer, caster, dan the electric arc furnaces (EAFs). Pengurangan emisi tersebut tidak dimungkinkan dengan menggunakan teknologi konvensional, namun dapat dicapai dengan penggunaan teknologi baru misalnya dengan menggunakan hidrogen sebagai pengganti karbon untuk proses reduksi biji besi.

Sementara bagi industri pulp diketahui bahwa pabrik pulp dan kertas modern sudah dapat mengurangi emisi karbon secara radikal 
melalui kombinasi perubahan proses produksi dan penggunaan alat purifikasi. Sementara itu, bagi industri semen, sebagian besar emisi $\mathrm{CO}_{2}$ yang dihasilkan oleh industri semen merupakan hasil reaksi kimia yang diperlukan untuk mengkonversi bahan mentah dan bukanlah merupakan dampak energi yang dibutuhkan untuk menghasilkan reaksi kimia tersebut.

Dengan demikian pengurangan emisi $\mathrm{CO}_{2}$ dapat dicapai dengan cara: (i) mengubah proses produksi dan manufaktur dan (ii) menyesuaikan komposisi kimia dari semen. Proses produksi dan manufaktur dapat dilakukan melalui memperbaiki manajemen energi dan investasi pada peralatan/perlengkapan baru atau upgrade. Perubahan formulasi kimia semen dapat dilakukan melalui penggunaan fuel yang tidak mengandung $\mathrm{CO}_{2}$, seperti biomass. Namun diakui, membangun standar industri yang baru bersifat kompleks serta membutuhkan waktu dan biaya.

Maka akhirnya, agar kebijakan-kebijakan tersebut dapat berubah dikategorikan dari berpotensi efektif menjadi berlaku efektif dalam upaya mitigasi perubahan iklim, perlu disusun peraturan-peraturan pelaksana agar insentif fiskal yang ditawarkan dapat secara aktif dimanfaatkan oleh pelaku usaha pada industri baja, semen, dan pulp.

\section{Input Non-energi}

Identifikasi terhadap UU dan peraturan yang ada menunjukkan bahwa pada tahap penggunaan input usaha non-energi, belum ada peraturan yang secara spesifik mengatur tentang insentif fiskal terkait upaya mitigasi perubahan iklim pada industri baja, semen, dan pulp. Namun terdapat masing-masing satu buah peraturan yang secara spesifik mengatur industri baja, semen dan pulp, serta terdapat empat peraturan yang mengatur penanaman modal di semua industri terkait input nonenergi.

Yang dimaksud dengan input non-energi dapat berupa pembelian bahan baku/bahan penolong non-energi, barang modal, mesin dan peralatan. Penjelasan atas peraturan-peraturan tersebut disajikan pada Tabel 3.

Tabel 3.

Instrumen Fiskal Mitigasi Perubahan Iklim dan Perlindungan Lingkungan-Tahap Input Non-energi

\begin{tabular}{|c|c|c|c|c|c|}
\hline Sektor & Peraturan & Tentang & Insentif Fiskal & Syarat & Analisis Efektivitas \\
\hline \multirow[t]{2}{*}{ Baja } & \multirow[t]{2}{*}{ PP 52/2011 } & \multirow[t]{2}{*}{$\begin{array}{l}\text { Fasilitas } \\
\text { PPh Untuk } \\
\text { Penanaman } \\
\text { Modal }\end{array}$} & $\begin{array}{l}\text { Pengurangan penghasilan } \\
\text { neto: } 30 \text { persen dari } \\
\text { Penanaman Modal, } \\
\text { dibebankan selama enam } \\
\text { tahun, masing-masing } \\
\text { sebesar } 5 \text { persen/ tahun }\end{array}$ & $\begin{array}{l}\text { 1) Pengolahan bijih } \\
\text { besi, Besi dan } \\
\text { Baja Paduan: Alih } \\
\text { teknologi }\end{array}$ & \multirow[t]{2}{*}{$\begin{array}{l}\text { - Searah dengan kebijakan } \\
\text { pengembangan industri } \\
\text { baja sesuai dengan } \\
\text { keunggulan daerah } \\
\text { - Tidak mengatur } \\
\text { perlindungan terhadap } \\
\text { lingkungan }\end{array}$} \\
\hline & & & $\begin{array}{l}\text { Penyusutan dan amortisasi } \\
\text { yang dipercepat untuk } \\
\text { barang bangunan dan } \\
\text { bukan bangunan }\end{array}$ & $\begin{array}{l}\text { 2) Besi \& baja } \\
\text { bentuk kasar: } \\
\text { - Kalimantan, } \\
\text { Banten } \\
\text { - Investasi > Rp } \\
400 \mathrm{M} \\
\text { - TK> } 100 \text { orang } \\
\text { 3) Baja Terintegrasi } \\
\text { Proses Kontinyu: } \\
\text { - Kalimantan, } \\
\text { Banten } \\
\text { - Investasi > Rp } 1 \mathrm{~T} \text {, } \\
\text { - TK> } 100 \text { org }\end{array}$ & \\
\hline
\end{tabular}


Sambungan dari halaman 86

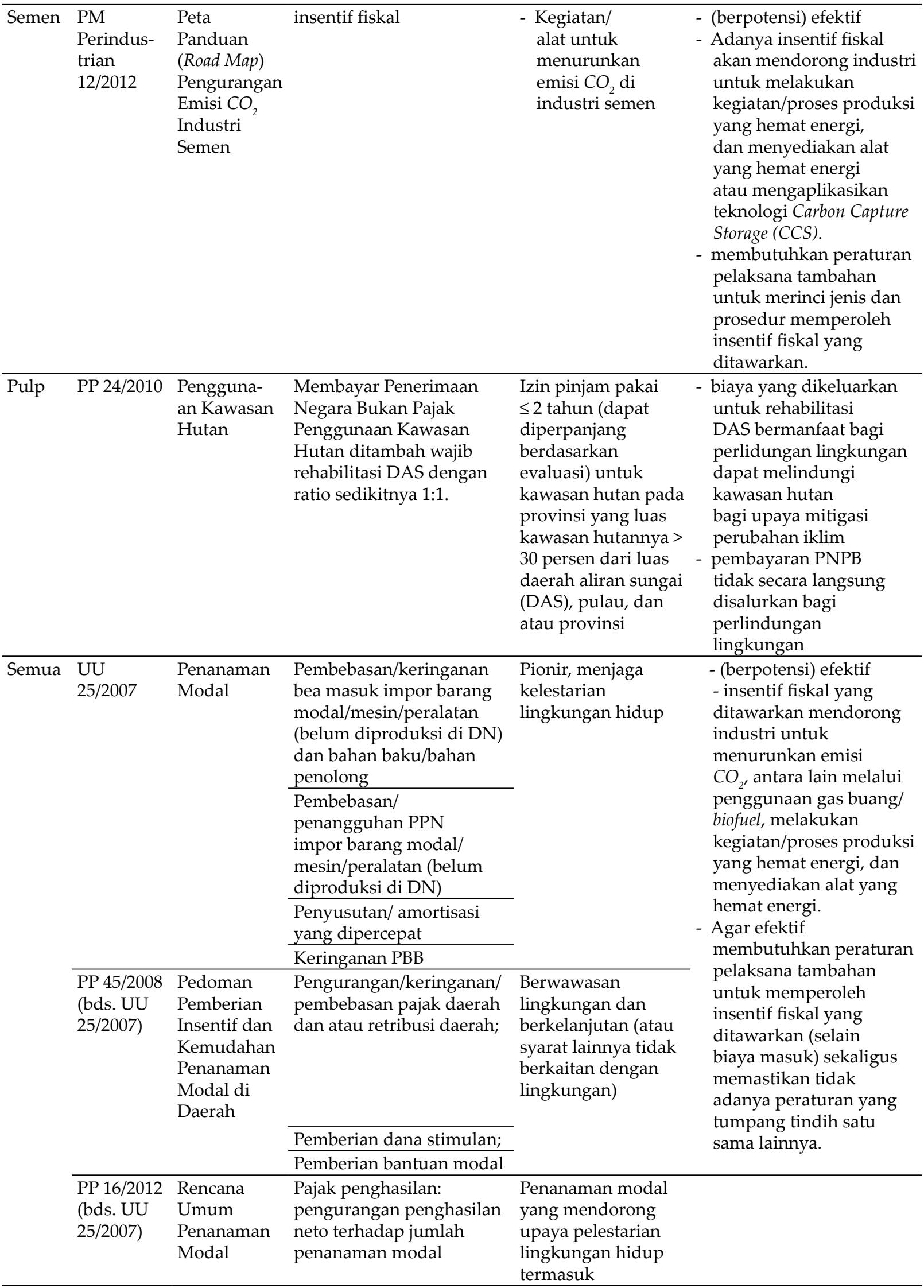


Sambungan dari halaman 87

\begin{tabular}{|c|c|c|c|}
\hline & & $\begin{array}{l}\text { Pembebasan/keringanan } \\
\text { bea masuk impor barang } \\
\text { modal/mesin/peralatan } \\
\text { belum diproduksi di DN }\end{array}$ & \multirow{5}{*}{$\begin{array}{l}\text { pencegahan } \\
\text { pencemaran, } \\
\text { pengurangan } \\
\text { pencemaran } \\
\text { lingkungan, } \\
\text { serta mendorong } \\
\text { perdagangan } \\
\text { karbon (carbon trade) }\end{array}$} \\
\hline & & $\begin{array}{l}\text { Pembebasan/keringanan } \\
\text { bea masuk bahan baku/ } \\
\text { bahan penolong }\end{array}$ & \\
\hline & & $\begin{array}{l}\text { Pembebasan/penang- } \\
\text { guhan PPN impor barang } \\
\text { modal/mesin/peralatan } \\
\text { belum diproduksi di DN }\end{array}$ & \\
\hline & & $\begin{array}{l}\text { Penyusutan atau } \\
\text { amortisasi yang dipercepat }\end{array}$ & \\
\hline & & Keringanan PBB & \\
\hline $\begin{array}{l}\text { PMK } \\
76 / 2012 \\
\text { (mengubah } \\
\text { PMK } \\
\text { 176/2009) }\end{array}$ & $\begin{array}{l}\text { Pembebasan } \\
\text { Bea Masuk } \\
\text { Atas Impor } \\
\text { Mesin Serta } \\
\text { Barang dan } \\
\text { Bahan Untuk } \\
\text { Pemba- } \\
\text { ngunan/ } \\
\text { Pengem- } \\
\text { bangan } \\
\text { Industri } \\
\text { Dalam } \\
\text { Rangka } \\
\text { Penanaman } \\
\text { Modal }\end{array}$ & $\begin{array}{l}\text { Pembebasan bea masuk } \\
\text { impor mesin selama empat } \\
\text { tahun. } \\
\text { (Dapat diperpanjang } \\
\text { maksimal dua tahun jika } \\
\text { tambah kapasitas } \geq 30 \\
\text { persen kapasitas terpasang } \\
\text { atau sesuai surat } \\
\text { penanaman modal.) }\end{array}$ & $\begin{array}{l}\text { - Mesin belum } \\
\text { diproduksi di DN/ } \\
\text { sudah diproduksi } \\
\text { namun belum } \\
\text { memenuhi } \\
\text { spesifikasi/ } \\
\text { jumlahnya belum } \\
\text { mencukupi } \\
\text { kebutuhan. } \\
\text { - Menggunakan } \\
\text { mesin produksi } \\
\text { DN } \geq 30 \text { persen } \\
\text { dari total nilai } \\
\text { mesin }\end{array}$ \\
\hline
\end{tabular}

Sumber: Data diolah

Pada industri baja, terdapat satu peraturan yang mengatur tentang insentif fiskal pada tahap ini, yaitu PP 52/2011. Meskipun tidak secara spesifik mengatur perlindungan terhadap lingkungan, namun insentif fiskal yang ditawarkan dalam peraturan ini berupa fasilitas PPh untuk penanaman modal, dapat dimanfaatkan oleh perusahaan pada industri baja melalui pengalihan alokasi dana yang semula digunakan untuk membayar PPh dapat dialihkan untuk mengganti bahan baku/bahan penolong non-energi, barang modal, mesin, atau peralatan agar dapat berproduksi secara lebih efisien dengan menggunakan teknologi terkini.

Berdasarkan kajian yang telah dilakukan oleh Kementerian Perindustrian RI (2012) diketahui bahwa dalam rangka melakukan total potensi penghematan energi pada industri baja sebesar 6.132.172,10 GJ dan penurunan total potensi emisi $\mathrm{CO}_{2}$ sebesar 2.644.103,40 ton hingga tahun 2020 diestimasi dibutuhkan investasi sebesar Rp196.878.243.000,00. Sebagai contoh, investasi tersebut dapat digunakan untuk membeli peralatan agar panas gas buang dapat dimanfaatkan untuk billet pre-heat maupun pemasangan peralatan meter energi.

Selain itu, penyusunan PP 52/2011 itu pun searah dengan kebijakan pengembangan industri baja sesuai dengan keunggulan daerah PM Perindustrian 12/2012 tentang Peta Panduan (road map) Pengurangan Emisi $\mathrm{CO}_{2}$ Industri Semen menyebutkan bahwa strategi kebijakan menurunkan emisi $\mathrm{CO}_{2}$ di industri semen antara lain melalui mekanisme insentif fiskal bagi kegiatan/alat untuk menurunkan emisi $\mathrm{CO}_{2}$ serta dukungan kebijakan pemberian insentif fiskal bagi yang menerapkan pemanfaatan gas buang sebagai sumber energi (heat recovery).

Dipaparkan sebelumnya dalam peraturan tersebut, potensi pengurangan emisi $\mathrm{CO}_{2}$ 
di industri semen dapat dilakukan dengan penggunaan energi alternatif, penggunaan bahan bakar alternatif, efisiensi energi, dan penerapan teknologi penangkapan atau penyimpanan karbon (Carbon Capture Storage (CCS)). Pemanfaatan bahan bakar alternatif dan gas buang (heat recovery) dapat dilakukan dengan ketersediaan alat yang mendukung.

Sebagai gambaran, Kementerian Perindustrian RI (2012) telah melakukan kajian dan mengestimasi dampak penggantian alat/ modifikasi peralatan bagi industri semen, yaitu dengan investasi (kumulatif) sebesar 436,6 juta Euro dapat diturunkan emisi kualitatif per tahun sebesar 14,093 $\mathrm{CO}_{2}$ ekuivalen (berdasarkan kondisi pada tahun 2010). Investasi tersebut antara lain dapat digunakan untuk mengganti peralatan sehingga dapat memanfaatkan gas buang (heat recovery) dalam proses pembuatan klinker dalam rotary kiln. Maka insentif fiskal yang disediakan tersebut diharapkan dapat secara efektif mendorong pengurangan emisi $\mathrm{CO}_{2}$ di industri semen.

Di dalam PP 24/2010 tentang penggunaan kawasan hutan diharapkan dapat mempengaruhi keputusan produksi perusahaan pada industri pulp. Diketahui, salah satu sumber bahan baku industri pulp adalah virgin fiber berbasis kayu segar yang diambil dari hutan. Kayu merupakan sumber daya alam yang terbarukan (Lembaga Manajemen FEUI, 2011). Namun hanya dengan pemanfaatan kayu yang diolah secara ramah lingkungan dan berkelanjutanlah yang dapat turut mendukung upaya pelestarian alam dan mitigasi perubahan iklim. Dengan adanya PP 24/2010 diharapkan industri pulp dapat memanfaatkan hutan dengan tetap memperhatikan daya dukung lingkungan. Bagi perusahaan yang memperoleh izin penggunaan kawasan hutan harus membayar Penerimaan Negara Bukan Pajak (PNBP) Penggunaan Kawasan Hutan ditambah wajib rehabilitasi Daerah Aliran Sungai (DAS) dengan rasio sedikitnya 1:1.
Biaya yang dikeluarkan untuk rehabilitasi DAS akan langsung bermanfaat terhadap perlindungan lingkungan. Pembayaran PNBP akan mendorong pengusaha beroperasi secara lebih efisien dengan upaya meminimalisasi biaya penggunaan input kayu dari luas hutan tertentu. Insentif fiskal pembayaran PNBP dengan alasan tersebut dapat dinilai berpotensi efektif dalam mendukung upaya perlindungan lingkungan dan mitigasi perubahan iklim. Namun agar lebih efektif dampaknya terhadap penurunan emisi $\mathrm{CO}_{2}$, perlu dipastikan agar dana PNPB disalurkan untuk kegiatan rehabilitasi lingkungan, karena kewajiban rehabilitasi untuk pengusaha hanyalah sebatas pada wilayah DAS.

Kewajiban rehabilitasi dibuat agar tidak terbatas pada daerah DAS. Dengan demikian perlu dibuat mekanisme evaluasi pada awal dan akhir masa penggunaan izin pinjam pakai kawasan hutan terhadap kerusakan hutan yang diakibatkan dan kewajiban rehabilitasi yang harus dilakukan. Selain itu, bagi industri pulp, salah satu sumber alternatif bahan baku lainnya dapat diperoleh dari kertas bekas (daur ulang). Bagi industri pulp dunia, hal ini sudah menjadi alternatif utama, karena selain lebih ramah lingkungan juga berbiaya rendah (Lembaga Manajemen FEUI, 2011).

Namun berdasarkan hasil Focus Group Discussion (FGD) dengan melibatkan asosiasi pulp dan kertas Indonesia diketahui bahwa biaya rendah yang lazim diharapkan di negara lain tidak dapat dicapai di Indonesia. Diperoleh informasi bahwa bea masuk impor biaya masuk kertas di Indonesia sangat tinggi sehingga pengusaha tetap memilih memperoleh input bahan baku dari virgin fiber. Bea masuk impor tinggi karena dibutuhkan waktu dan upaya oleh pihak bea cukai untuk memastikan produk yang diimpor adalah produk yang aman.

Hal ini menjadi salah satu contoh masih terdapatnya peraturan yang tumpang tindih, yaitu adanya peraturan yang menghambat efektivitas peraturan yang telah dibuat 
dalam upaya mitigasi perubahan iklim. Direktur Eksekutif Asosiasi Pulp dan Kertas Indonesia menyebutkan bahwa di luar negeri, pemeriksaan terhadap limbah kertas dapat dilakukan dengan menggunakan suatu alat tanpa membongkar isi kemasan secara fisik yang memakan waktu dan biaya. Meskipun alat tersebut membutuhkan biaya namun manfaatnya dapat digunakan secara optimal bagi perkembangan industri pulp yang ramah lingkungan.

Adanya peraturan yang saling bertentangan dampaknya terhadap pengurangan emisi $\mathrm{CO}_{2}$ (tumpang tindih) juga terdapat pada masalah non-energi pada industri semen. Diketahui bahwa secara teknis, rasio klinker yang lebih rendahakan menurunkan emisi $\mathrm{CO}_{2}$. Bahan pencampur yang dapat menggantikan klinker ialah abu terbang ( $f l y$ ash) dari pembangkit listrik tenaga uap. Namun terdapat hambatan bagi penggunaan bahan pengganti klinker karena terdapat peraturan lingkungan PMNLH No. 18 Tahun 2009 yang menggolongkan abu terbang sebagai limbah Bahan Berbahaya dan Beracun (B3), sehingga menghambat rantai pemasokan input produksi yang dapat menurunkan emisi $\mathrm{CO}_{2}$.

Tentang peraturan lainnya pada Tabel 3.3 ialah terkait penanaman modal. Ketiga peraturan, yaitu UU 25/2007, PP 45/2008, dan PP 16/2012, menjelaskan penawaran berbagai insentif fiskal bagi input energi maupun input non-energi. Insentif fiskal yang ditawarkan yaitu pembebasan/keringanan bea masuk impor barang modal/mesin/peralatan yang belum diproduksi di dalam negeri dan bahan baku/bahan penolong, pembebasan/ penangguhan PPN impor barang modal/ mesin/ peralatan, penyusutan/amortisasi yang dipercepat, keringanan $\mathrm{PBB}$, pengurangan/ keringanan/pembebasan pajak daerah dan atau retribusi daerah, pemberian dana stimulan, dan pemberian bantuan modal.

Namun hanya satu peraturan pelaksana yang telah dibuat untuk mendukung pemanfaatan insentif yang ada, yaitu PMK 76/2012 yang mengatur tentang Pembebasan Bea Masuk Atas Impor Mesin Serta Barang dan Bahan Untuk Pembangunan/Pengembangan Industri dalam Rangka Penanaman Modal, yaitu berupa pengaturan insentif pembebasan bea masuk impor mesin selama empat tahun, di mana dapat diperpanjang maksimum hingga dua tahun jika tambah kapasitas $\geq 30$ persen dari kapasitas terpasang atau sesuai surat penanaman modal.

Seluruh insentif fiskal yang telah ditawarkan tersebut sangat berpotensi efektif dalam mendukung upaya mitigasi perubahan iklim, karena seperti yang telah disebutkan sebelumnya, pada dasarnya untuk melakukan efisiensi energi sekaligus pengurangan emisi $\mathrm{CO}_{2}$ dapat dilakukan melalui prosedur:

a) Perubahan proses manufaktur dan produksi (termasuk pergantian alat produksi agar dapat menggunakan energi secara lebih efisien).

b) Menyesuaikan komposisi kimia yang diperlukan

c) Mengganti bahan bakar fosil dengan biomass atau gas buang

Sebagai gambaran terhadap efek penggantian alat/modifikasi peralatan bagi industri pulp, berdasarkan hasil kajian Kementerian Perindustrian (2012) diketahui bahwa guna mencapai total potensi penghematan energi sebesar 51.254.695 GJ dan penurunan total potensi emisi $\mathrm{CO}_{2}$ sebesar 3.155.386 ton $\mathrm{CO}_{2}$ hingga tahun 2020, diestimasi kebutuhan biaya investasi yang diperlukan ialah sebesar Rp540.587.867.000,00. Sebagai contoh, investasi tersebut diperlukan untuk penggantian mesin diesel modern agar dapat menggunakan bahan bakar biofuel sintesis dari proses gasifikasi spent liquor.

Sementara itu, hasil estimasi kebutuhan investasi untuk penurunan emisi kualitatif per tahun dan potensi penghematan energi tertentu pada industri baja dan semen ialah sebagaimana 
yang telah disampaikan sebelumnya. Akhirnya karena peraturan pelaksana masih terbatas, insentif-insentif fiskal untuk penggantian alat/ modifikasi peralatan ataupun input nonenergi lainnya tersebut belum secara optimal mendukung upaya mitigasi perubahan iklim.

\section{Proses Industri}

Berdasarkan identifikasi yang dilakukan terhadap undang-undang dan peraturan yang ada, saat ini hanya terdapat satu peraturan yang secara spesifik mengatur pelaksanaan usaha (operasi) bagi industri tertentu, yaitu bagi industri pulp. Dari peraturan yang ada, hanya dua peraturan yang menyinggung secara spesifik tentang upaya mitigasi perubahan iklim. Secara umum terdapat empat peraturan terkait perlindungan lingkungan yang berlaku bagi seluruh industri perihal operasi usaha, yaitu UU/peraturan yang mengatur tentang perlindungan lingkungan hidup, manajemen energi, dan aturan tentang pajak ditanggung pemerintah. Deskripsi atas peraturan-peraturan tersebut disajikan pada Tabel 4.

Berdasarkan Peraturan Menteri Perindustrian No. 121/2009, industri pulp yang

Tabel 4.

Instrumen Fiskal Mitigasi Perubahan Iklim dan Perlindungan Lingkungan-Tahap Operasi

\begin{tabular}{|c|c|c|c|c|c|}
\hline Sektor & Peraturan & Tentang & Insentif Fiskal & Syarat & Analisis Efektivitas \\
\hline Pulp & $\begin{array}{l}\text { PM } \\
\text { Perindustrian } \\
\text { No. 121/2009 }\end{array}$ & $\begin{array}{l}\text { Peta Panduan } \\
\text { (road map) } \\
\text { Pengembangan } \\
\text { Klaster Industri } \\
\text { Kertas } \\
\end{array}$ & $\begin{array}{l}\text { Pemberian insentif, } \\
\text { berupa: kredit lunak, } \\
\text { keringanan pajak, dll }\end{array}$ & $\begin{array}{l}\text { Perusahaan } \\
\text { HPHTI } \\
\text { melakukan } \\
\text { percepatan } \\
\text { penanaman }\end{array}$ & $\begin{array}{l}\text { - (berpotensi efektif) agar } \\
\text { industri kertas melakukan } \\
\text { upaya percepatan } \\
\text { penanaman mendukung } \\
\text { mitigasi perubahan iklim }\end{array}$ \\
\hline \multirow[t]{2}{*}{ Semua } & PP 28/2008 & $\begin{array}{l}\text { Kebijakan } \\
\text { Industri } \\
\text { Nasional }\end{array}$ & Insentif Fiskal & $\begin{array}{l}\text { Menjaga } \\
\text { kelestarian } \\
\text { lingkungan } \\
\text { hidup }\end{array}$ & $\begin{array}{l}\text { - berperan sebagai aturan } \\
\text { dasar tentang adanya } \\
\text { pemberian insentif fiskal } \\
\text { demi menjaga kelestarian } \\
\text { lingkungan hidup } \\
\text { - membutuhkan peraturan } \\
\text { pelaksana tambahan } \\
\text { untuk merinci jenis dan } \\
\text { prosedur memperoleh } \\
\text { insentif fiskal yang } \\
\text { ditawarkan dan } \\
\text { konsistensi peraturan } \\
\text { yang telah ada }\end{array}$ \\
\hline & UU 32/2009 & $\begin{array}{l}\text { Perlindungan } \\
\text { dan } \\
\text { Pengelolaan } \\
\text { Lingkungan } \\
\text { Hidup }\end{array}$ & $\begin{array}{l}\text { Insentif/disinsentif } \\
\text { yaitu pajak, retribusi, } \\
\text { dan subsidi lingkungan } \\
\text { hidup }\end{array}$ & $\begin{array}{l}\text { Melestari- } \\
\text { kan fungsi } \\
\text { lingkungan } \\
\text { hidup }\end{array}$ & $\begin{array}{l}\text { - berperan sebagai aturan } \\
\text { dasar tentang adanya } \\
\text { pemberian insentif fiskal } \\
\text { demi menjaga kelestarian } \\
\text { lingkungan hidup, } \\
\text { di mana Pemerintah } \\
\text { (nasional/daerah) wajib } \\
\text { menyusun Rencana } \\
\text { Perlindungan dan } \\
\text { Pengelolaan Lingkungan } \\
\text { Hidup (RPPLH), meliputi } \\
\text { pelestarian fungsi } \\
\text { atmosfer, termasuk upaya } \\
\text { mitigasi dan adaptasi } \\
\text { perubahan iklim, a.l } \\
\text { dengan menerapkan } \\
\text { instrumen ekonomi }\end{array}$ \\
\hline
\end{tabular}


Sambungan dari halaman 91

\begin{tabular}{|c|c|c|c|c|}
\hline & & $\begin{array}{l}\text { denda } \leq \\
\text { Rp1.000.000.000,00 }\end{array}$ & $\begin{array}{l}\text { Tidak } \\
\text { melaksanakan } \\
\text { paksaan } \\
\text { pemerintah } \\
\text { (melampaui } \\
\text { baku mutu } \\
\text { lingkungan } \\
\text { hidup: air, } \\
\text { limbah, udara, } \\
\text { emisi, dll) }\end{array}$ & $\begin{array}{l}\text { - berproduksi dalam } \\
\text { batas baku emisi yang } \\
\text { ditetapkan sangat efektif } \\
\text { menjaga secara agregat } \\
\text { tercapainya upaya mitigasi } \\
\text { perubahan iklim } \\
\text { - pemerintah pusat dan } \\
\text { daerah perlu menyiapkan } \\
\text { aturan pelaksana agar } \\
\text { insentif dan disinsentif } \\
\text { tersebut dapat diterapkan } \\
\text { bagi pihak industri. } \\
\end{array}$ \\
\hline UU 11/2011 & $\begin{array}{l}\text { APBN Tahun } \\
2012\end{array}$ & $\begin{array}{l}\text { Pajak ditanggung } \\
\text { pemerintah (DTP) atas: } \\
\text { Adaptasi dan Mitigasi } \\
\text { Perubahan Iklim } \\
\text { sebesar Rp0,00 (nihil), } \\
\text { sebelumnya: } \\
\text { (sebelumnya: } \\
\text { - UU 2/2010 untuk } \\
\text { Tahun 2010: } \\
\text { Rp900.000.000.000,00 } \\
\text { - UU 10/2010 untuk } \\
\text { Tahun 2011: } \\
\text { Rp500.000.000.000,00 }\end{array}$ & $\begin{array}{l}\text { Berwawasan } \\
\text { lingkungan dan } \\
\text { berkelanjutan } \\
\text { (atau syarat } \\
\text { lainnya tidak } \\
\text { berkaitan } \\
\text { dengan } \\
\text { lingkungan) }\end{array}$ & $\begin{array}{l}\text { Peraturan ini tidak efektif } \\
\text { dalam mendukung upaya } \\
\text { mitigasi perubahan iklim. } \\
\text { Penghapusan anggaran } \\
\text { ini menyebabkan insentif } \\
\text { fiskal yang ada pada aturan } \\
\text { sebelumnya mengenai pajak } \\
\text { ditanggung pemerintah } \\
\text { tidak dapat dilaksanakan }\end{array}$ \\
\hline
\end{tabular}

Sumber: Data diolah

mendapat hak pengelolaan Hutan Tanaman Industri (HTI) dapat memperoleh insentif berupa kredit lunak dan keringanan pajak jika melakukan percepatan penanaman. Insentif ini jelas dapat mendukung upaya mitigasi perubahan ilkim dan konsisten dengan PP 24/2010 tentang Penggunaan Kawasan Hutan. Namun, kedua peraturan tersebut belum memberikan penjelasan atas prosedur pemberian insentif sehingga belum dapat dimanfaatkan secara optimal oleh pihak swasta.

Di dalam PP 28/2008 tentang Kebijakan Industri Nasional telah menyebutkan pemberian insentif fiskal bagi industri yang menjaga kelestarian lingkungan hidup. Namun aturan tersebut belum secara spesifik mendeskripsikan jenis insentif fiskal apa saja yang ditawarkan bagi industri. Demikian juga dengan UU 32/2009 tentang Perlindungan dan Pengelolaan Lingkungan Hidup yang menawarkan insentif (disinsentif) yaitu pajak, retribusi, dan subsidi lingkungan hidup bagi pihak yang melestarikan fungsi lingkungan hidup, serta denda sebesar kurang dari Rp1.000.000.000,00 bagi yang tidak melaksanakan paksaan pemerintah (melampaui baku mutu lingkungan hidup: air, limbah, udara, emisi, dll).

Namun penjelasan spesifik mengenai insentif audit energi dan disinsentif denda yang dikenakan belum diberikan, sehingga pemanfaatan oleh pihak industri belum dapat dilakukan. Hal tersebut mungkin dikarenakan UU tersebut berperan sebagai aturan dasar tentang adanya pemberian insentif fiskal demi menjaga kelestarian lingkungan hidup, di mana Pemerintah (nasional/daerah) wajib menyusun Rencana Perlindungan dan Pengelolaan Lingkungan Hidup (RPPLH), meliputi pelestarian fungsi atmosfer, termasuk upaya mitigasi dan adaptasi perubahan iklim, yaitu antara lain dengan menerapkan instrumen ekonomi yang sesuai.

Khususnya terkait disinsentif denda, sesungguhnya disinsentif ini berpotensi efektif demi menjaga produksi secara agregat berada dalam dalam batas baku emisi yang ditetapkan. 
Dengan demikian, pemerintah pusat dan daerah perlu menyiapkan aturan pelaksana agar insentif dan disinsentif tersebut dapat diterapkan bagi pihak industri. UU 11/2011 tentang APBN Tahun 2012 menyebutkan pajak ditanggung pemerintah (DTP) atas komponen adaptasi dan mitigasi perubahan iklim diturunkan dari tahun sebelumnya menjadi Rp0,00 (nihil) karena dianggap merupakan sangat tidak efektif dalam mendukung upaya mitigasi perubahan iklim. Penghapusan anggaran ini menyebabkan insentif fiskal yang telah ditawarkan pada aturan-aturan lainnya mengenai perlindungan lingkungan dan mitigasi perubahan iklim, khususnya mengenai penawaran insentif mengenai pajak ditanggung pemerintah tidak dapat dilaksanakan (contohnya pada UU 32/2009).

Sebagai akibatnya, target penurunan emisi gas rumah kaca (GRK) sebesar 26 persen (dengan upaya dalam negeri), atau lebih spesifik yaitu penurunan emisi dari bidang industri sebesar satu juta $\mathrm{TCO}_{2}$ (26 persen) sampai tahun 2020 sesuai Perpres 61/2011, kian sulit dapat tercapai. Rendahnya penyerapan anggaran untuk komponen DTP bagi adaptasi dan mitigasi perubahan iklim pada suatu periode hendaknya direspons dengan mengupayakan berbagai langkah-langkah peningkatan penyerapan oleh industri, dan bukan dengan penghapusan mata anggaran terkait.

\section{Manajemen Limbah/Gas/Zat Buang (Waste Management)}

Berdasarkan identifikasi yang dilakukan terhadap undang-undang dan peraturan yang ada, saat ini hanya terdapat satu peraturan yang secara spesifik mengatur manajemen limbah bagi industri tertentu, yaitu bagi industri semen. Serta terdapat satu peraturan terkait manajemen limbah yang mengatur semua industri. Deskripsi atas peraturan-peraturan tersebut disajikan pada Tabel 5.

Di dalam PM Perindustrian 12/2012 tentang Peta Panduan (road map) Pengurangan
Emisi $\mathrm{CO}_{2}$ Industri Semen menyebutkan bahwa strategi kebijakan menurunkan emisi $\mathrm{CO}_{2}$ pada industri semen antara lain melalui mekanisme insentif fiskal bagi kegiatan/alat untuk menurunkan emisi $\mathrm{CO}_{2}$ dan dukungan kebijakan pemberian insentif fiskal bagi industri yang menerapkan pemanfaatan gas buang sebagai sumber energi (heat recovery). Diketahui bahwa potensi pengurangan emisi $\mathrm{CO}_{2}$ di industri semen dapat dilakukan dengan penggunaan energi alternatif, penggunaan bahan bakar alternatif, efisiensi energi, dan penerapan teknologi penangkapan atau penyimpanan karbon (Carbon Capture Storage (CCS).

Dari antara kegiatan tersebut, terkait limbah, pabrik semen dapat menggunakan limbah industri dan limbah domestik (sampah tersortir) sebagai bahan bakar alternatif, termasuk limbah kayu dan limbah tembakau. Pemanfaatan limbah sebagai bahan bakar tersebut dapat mendukung perlindungan lingkungan. Selain itu, khususnya melalui pelaksanaan teknologi CCS, pabrik semen dapat menyerap limbah karbon yang dihasilkan dalam proses produksi, atau dengan ketersediaan alat yang mendukung, pabrik semen dapat menggunakan gas buang, misalnya dalam proses pembuatan klinker dalam rotary kiln.

Sementara itu, PP 28/2008 tentang Kebijakan Industri Nasional hanya menyebutkan pemberian insentif fiskal bagi pihak yang menjaga kelestarian lingkungan hidup, meskipun berarti termasuk di dalamnya pengolahan limbah. Namun untuk kedua peraturan tersebut masih diperlukan peraturan pelaksana yang merinci jenis dan prosedur untuk memperoleh insentif fiskal yang ditawarkan, khususnya terkait pengolahan atau pemanfaatan limbah.

Demikianlah berbagai insentif fiskal yang telah ditawarkan pada berbagai peraturan yang ada yang dikategorisasi berdasarkan tahapan usaha yaitu memulai usaha (starting business), input energi, input non-energi, operasi 
Tabel 5.

Instrumen Fiskal Mitigasi Perubahan Iklim dan Perlindungan Lingkungan-Tahap Manajemen Limbah

\begin{tabular}{|c|c|c|c|c|c|}
\hline Sektor & Peraturan & Tentang & $\begin{array}{c}\text { Insentif } \\
\text { Fiskal }\end{array}$ & Syarat & Analisis Efektivitas \\
\hline Semen & $\begin{array}{l}\text { PM } \\
\text { Perindustrian } \\
12 / 2012\end{array}$ & $\begin{array}{l}\text { Peta } \\
\text { Panduan } \\
\text { (road map) } \\
\text { Pengurang- } \\
\text { an Emisi } \\
\mathrm{CO}_{2} \text { Industri } \\
\text { Semen }\end{array}$ & $\begin{array}{l}\text { insentif } \\
\text { fiskal }\end{array}$ & $\begin{array}{l}\text { - Kegiatan/alat untuk } \\
\text { menurunkan emisi } \\
\mathrm{CO}_{2} \text { di industri } \\
\text { semen (salah } \\
\text { satunya melalui } \\
\text { teknologi Carbon } \\
\text { Capture Storage } \\
\text { (CCS) yaitu upaya } \\
\text { menangkap dan } \\
\text { menyerap karbon } \\
\text { selama proses, } \\
\text { untuk menurunkan } \\
\text { emisi CO } \\
\text { - Industri yang } \\
\text { menerapkan } \\
\text { pemanfaatan gas } \\
\text { buang sebagai } \\
\text { sumber energi (heat } \\
\text { recovery) }\end{array}$ & $\begin{array}{l}\text { - (berpotensi) efektif } \\
\text { - Adanya insentif fiskal akan mendorong } \\
\text { industri untuk menurunkan emisi } \\
\mathrm{CO}_{2^{\prime}} \text { antara lain melalui penggunaan } \\
\text { gas buang/limbah/bio-fuel, melakukan } \\
\text { kegiatan/proses produksi yang hemat } \\
\text { energi, dan menyediakan alat yang } \\
\text { hemat energi atau mengaplikasikan } \\
\text { teknologi Carbon Capture Storage } \\
\text { (CCS) yaitu upaya menangkap dan } \\
\text { menyerap karbon selama proses, } \\
\text { untuk menurunkan emisi CO } \\
\text { - membutuhkan peraturan pelaksana } \\
\text { tambahan untuk merinci jenis dan } \\
\text { prosedur memperoleh insentif fiskal } \\
\text { yang ditawarkan, khususnya terkait } \\
\text { pemanfaatan limbah }\end{array}$ \\
\hline Semua & PP 28/2008 & $\begin{array}{l}\text { Kebijakan } \\
\text { Industri } \\
\text { Nasional }\end{array}$ & $\begin{array}{l}\text { Insentif } \\
\text { Fiskal }\end{array}$ & $\begin{array}{l}\text { Menjaga kelestarian } \\
\text { lingkungan hidup }\end{array}$ & $\begin{array}{l}\text { - berperan sebagai aturan dasar tentang } \\
\text { adanya pemberian insentif fiskal } \\
\text { demi menjaga kelestarian lingkungan } \\
\text { hidup, khususnya pengolahan limbah } \\
\text { - membutuhkan peraturan pelaksana } \\
\text { tambahan untuk merinci jenis dan } \\
\text { prosedur memperoleh insentif fiskal } \\
\text { yang ditawarkan dan konsistensi } \\
\text { peraturan yang telah ada, khususnya } \\
\text { terkait pengolahan limbah }\end{array}$ \\
\hline
\end{tabular}

Sumber: Data diolah

usaha, manajemen gas/zat buang (waste management). Berdasarkan analisis efektivitas yang telah dilakukan, insentif-insentif fiskal yang ditawarkan sesungguhnya cukup berpotensi untuk mengurangi emisi $\mathrm{CO}_{2}$, namun belum dapat evaluasi secara empiris karena pemanfaatannya masih sangat kurang bahkan nihil, dikarenakan ketiadaan peraturanperturan pelaksana yang mendukung dan adanya beberapa peraturan yang menghambat efektivitas kebijakan tersebut.

\section{Kesimpulan dan Rekomendasi}

First best policy adalah diterapkannya carbon tax di mana penggunaan energi berbasis karbon akan meningkat harganya sehingga memicu pelaku usaha untuk menggunakan energi terbarukan. Selain itu pencapaian target pengurangan emisi secara pada sektor industri memerlukan sinergi berbagai kebijakan sektor Industri (khususnya terkait industri baja, tekstil dan semen sebagai emiten terbesar) hendaknya juga mencantumkan pengurangan emisi sehingga pendekatannya tidak parsial dan bergantung pada beberapa instrumen kebijakan saja.

Salah satu butir pada PP 28/2008 tentang Kebijakan Industri Nasional adalah mengembangkan industri sambil tetap menjaga kelestarian lingkungan hidup. Namun PMK 76/2012 (mengubah PMK 176/2009) tentang pembebasan bea impor untuk mesin dan bahan antara tidak menyebutkan penurunan emisi sebagai salah satu konsideran. Demikian 
juga halnya dengan PMK 130/2011 tentang Tax Holiday, perlu dicatat bahwa kebijakan Tax Holiday di Thailand secara eksplisit menyebutkan usaha konservasi/alternatif energi dan eco-friendly product. PP 52/2011 tentang insentif $\mathrm{PPh}$ untuk penanaman modal juga tidak menyebutkan pengurangan emisi dan kelestarian lingkungan sebagai indikator pemberian insentif. Tiga regulasi dan insentif fiskal besar tersebut di tambahkan indikator faktor lingkungan dan pengurangan emisi, secara eksplisit.

Industri semen sudah ditetapkan road map pengurangan emisi melalui Permen Perindustrian 12/2012 namun belum ada Permen serupa untuk industri besi baja serta pulp dan kertas. Memang terdapat Permen 103/2009 tentang Peta Panduan (road map) Pengembangan Klaster Industri Baja dan Permen 121/2009 tentang Peta Panduan (road map) Pengembangan Klaster Industri Kertas. Namun kedua Permen tersebut tidak secara fokus dan spesifik membahas tentang pengurangan emisi. Permen tentang pengurangan emisi industri semen memang berisikan target kuantitatif penurunan emisi, namun tidak memuat skema reward/punishment apapun. Dibutuhkan Peraturan Menteri untuk pengurangan emisi pada industri pulp dan besi baja sebagai emiten yang cukup besar dengan target kuantitatif dan skema reward/punishment fiskal yang memadai.

Beberapa regulasi, seperti PP 70/2009 tentang Konservasi Energi, membutuhkan regulasi pendukung untuk meningkatkan efektifitasnya dalam mengurangi emisi. Peraturan turunannya, Permen ESDM 14/2012 menyatakan bahwa perusahaan yang memenuhi target akan dibiayai audit energi oleh pemerintah. Hal ini membuka celah untuk dilakukannya audit energi secara profesional (contoh: dibiayai Indonesia Climate Change Trust Fund ) untuk memberikan rekomendasi peningkatan efisiensi yang tinggi. Kementrian Perindustrian juga perlu mengidentifikasi teknologi pengurangan emisi pada industri semen, pulp dan kertas dan semen untuk diberikan insentif tambahan berupa bea masuk ditanggung pemerintah (BM DTP). Kerjasama dengan bea cukai untuk penggunaan alat yang dapat mengidentifikasi kontek tanpa perlu pemeriksaan fisik dibutuhkan untuk mendorong industri pulp kertas menggunakan kertas daur ulang dari luar negeri. Insentif tambahan bagi penghasil dan importir kertas daur ulang juga perlu dipertimbang secara serius.

\section{Daftar Pustaka}

Heede, Richard. (2007). Greenhouse Gas Emissions Inventory: Minnesota Steel Industries' Proposed Integrated Iron Mine, DRI, Taconite, and Steel Mill For Minnesota Center for Environmental Advocacy. Climate Mitigation Services.

Energy and Emission Reduction Opportunities from Cement Industry, US Department of Energy.

Kementrian Lingkungan Hidup. (2010). Indonesia Second National Communication to UNFCC.

Lembaga Manajemen FEUI. (2011). Analisis Industri Pulp dan Kertas Dunia. Masukan bagi Pengelola BUMN. Biro Riset Lembaga Manajemen FEUI.

M. Kundak, L. LasiJ, J. RNKO. (2008). $\mathrm{CO}_{2}$ Emission in the Steel Industry. Metalurgi: 193-197.

Martawardaya, Berly \& Maria Agriva. (2012). Tax Holiday: Konsep, Success Story $\mathcal{E}$ Penarapan di Indonesia. Unpublished study for Indonesian Ministry of Industry.

Modjo, Ikhsan \& Berly Martawardaya. (2011). Economic Instruments for the Indonesian Industry to Reduce Emissions of Greenhouse Gasses. Report for PAKLIM GIZ.

UNICEF. (2008). Writing a Communication Strategy for Development. 


\section{Internet}

2011 Laporan Tahunan Annual Report (2012). (Online). (http://www.bakrie-brothers.com/ uploads/dlfile/file_73b3efd834cb9289e7404f3 39cb12cc7.pdf, diakses 05 Desember 2012).

Asia Pulp and Paper. (2012). (Online). (http:// www.asiapulppaper.com/, diakses 03 Desember 2012).

Available and Emerging Technologies for Reducing Greenhouse Gas Emission from the Pulp and Paper Manufacturing Industry. (2012). (Online). (http://www.epa.gov/nsr/ghgdocs/ pulpandpaper.pdf, diakses 02 Desember 2012).

Bakrie \& Brothers. (2012). (Online). (http:// id.wikipedia.org/wiki/Bakrie_\%26_ Brothers, diakses 19 November 2012).

Bakrie Pipe Industries (2012). (Online). (http:// www.bakrie-metal.com/index.php/ourunits/bakrie-pipe-industries, diakses 05 Desember 2012).

BPKIMI (Badan Pengkajian Kebijakan Iklim dan Mutu Industri) - Kementrian Perindustrian. (www.bkimi.kemenperin.go.id).

Cara dan Trik. (2012). (Online). (http:// carantrik.blogspot.com/2010/11/ptgunawan-dianjaya-steel-tbk.html, diakses 03 Desember 2012).

Cement Calcining. (2012). (Online). (http:// www.sbmchina.com/cement_plant/ products/cement_calcining.html, diakses 16 November 2012).

Cement in Indonesia. (2012). (Online). (http:// www.globalcement.com/magazine/ articles/685-cement-in-indonesia, diakses 17 November 2012).

Cement Industry in Indonesia. (2012). (Online). (http://www.datacon.co.id/Cement2010Industry.html, diakses 18 November 2012).

Cement Manufacturing Process: components of a cement plant. (2012). (Online). (http://www.understanding-cement.com/ manufacturing.html, diakses 16 November 2012).
Cement. (2012). (Online). (http://en.wikipedia. org/wiki/Cement, diakses 16 November 2012).

ClimateTechWiki. (2012). (Online). (http:// climatetechwiki.org/technology/energysaving-cement, diakses 16 November 2012). . (2012). (Online). (http:// climatetechwiki.org/technology/energysaving-cement).

Ekamasfortuna industrial paper manufacturing. (2012). (Online). (http://ekamasfortuna. com/index.php/history-of-paper-pulp.htm, diakses 20 November 2012).

Emerging Markets Direct. (2012). (Online). (http://www.emergingmarketsdirect.com/ asia/indonesia-steel-industry-1h12/, diakses 19 November 2012).

Finance Roll. (2012). (Online). (http://financeroll. co.id/news/46190/volume-penjualan-turunpendapatan-jaya-pari-steel-terpangkassignifikan, diakses 19 November 2012).

Holcim. (2012). (Online). (http://www.scribd. com/doc/106892554/Holcim-Indonesia-AR2010, diakses 05 Desember 2012).

Indocement Heidelberg Cement Group. (2012). (Online). (http://www.indocement.co.id/ aspx/, diakses 18 Januari 2012).

Indonesia Cement Association, Cement up Date 2011. (2012). (Online). (http://www. asi.or.id/statis-11-statistic.html, diakses 17 November 2012.

Indonesian Commercial Newsletter. (2012). (Online). (http://www.datacon.co.id/ Cement-2010Industry.html, diakses 17 November 2012).

Komisaris Tonasa dan Konflik Kepentingan. (2012). (Online). (http://www.fajar.co.id/ read-20120625003117-komisaris-tonasadan-konflik-kepentingan, diakses 05 Desember 2012.

Kompas.com. (2012). (Online). (http:// bi sn is keu an gan.kom pas.com/ $\mathrm{read} / 2012 / 10 / 16 / 13452888 / D a h l a n . I s k a n$. Minta.Saham.Semen.Baturaja.Tidak. Diobral, diakses 05 Desember 2012). 
Krakatau Steel. (2012). (Online). (http://www. krakatausteel.com/?page $=$ content\&cid $=8$, diakses 19 November 2012).

Krakatau Steel. (2012). (Online). (http://www. krakatausteel.com/?page=viewnews\&act ion=view\&id=1603, diakses 03 Desember 2012).

Krakatau Steel. (2012). (Online). (http://www. krakatausteel.com/pdf/Krakatau_Steel_ Billingual_30_Sept_11_Released.pdf, diakses 03 Desember 2012).

Metal Bulletin Company Database. (2012). (Online). (http://www.mbdatabase.com/ GeneralInformation/PT\%20Gunawan\%20 Dianjaya\%20Steel\%20Tbk/16537, diakses 05 Desember 2012).

Produksi Baja. (2012). (Online). (http://aguzher. wordpress.com/2008/01/18/prosesproduksi-baja/, diakses 18 November 2012).

Proses Pembuatan Pulp dan Kertas. (2012). (Online). (http://note-why.blogspot. com/2012/07/proses-pembuatan-kertas. html, diakses 03 Desember 2012).

PT. Indocement Tunggal Prakarsa Tbk dan entitas anak/ and subsidiaries. (2012). (Online). (http://www.indocement.co.id/ userfiles/file/Financial\%20Report/2012/ Indocement\%20Tunggal\%20Prakarsa_ Bilingual_30-Jun-12.pdf, diakses 05 Desember 2012).

PT. Jaya Pari Steel. (2012). (Online). (http:// www.jayaparisteel.co.id/ina/faq/, diakses 19 November 2012).

PT. Jaya Pari Steel Tbk. Laporan Tahunan Annual Report 2011. (2012). (Online). (http://114.57.38.118/corporate_actions/ new_info_jsx/jenis_informasi/01_laporan_ keuangan/04_Annual\%20Report/2011/ JPRS/JPRS_AR\%202011.pdf, diakses 05 Desember 2012).

PT. Semen Baturaja Persero. (2012). (Online). (http://semenbaturaja.co.id/perusahaan. php, diakses 18 November 2012).

PT. Semen Gresik (Persero) Tbk. (2012). (Online). (http://www.semengresik.com/ ina/perusahaanRiwayat.aspx, diakses 05 Desember 2012).

PT. Semen Padang. (2012). (Online). ( h t t p : / / w w w. se m e n pad a n . co.id/?mod=profil\&kat=\&id=1, diakses 05 Desember 2012).

Pulp Making Process. (2012). (Online). (http:// www.asiapulppaper.com/portal/APP portal.nsf/0/5D0683EE6BFAB72B47257353 000983B3?OpenDocument $\&$ Key $=6 \& a c t v=$ 0, diakses 20 November 2012).

Statistik Semen Nasionak, Kapasitas Produksi Semen Nasional Per Tahun. (2012). (Online). (http:// pusbinsdi.net/semen.php?page=produksi, diakses 02 Desember 2012).

Tribun News.com: Produksi Semen Gresik Naik. (2012). (Online). (http://www.tribunnews. com/2012/07/18/produksi-semen-gresiknaik-115-persen, diakses 17 November 2012).

World Steel Association. (2012). (Online). (http://www.worldsteel.org/dms/ internetDocumentList/fact-sheets/Factsheet_Raw-materials2011/document/ Fact\%20sheet_Raw\%20materials2011.pdf, diakses 18 November 2012). 